Research Article

\title{
Price analysis of antianginal drugs available in Indian market
}

\author{
Vihang S. Chawan, Sagar V. Badwane*, Kalpesh V. Gawand, \\ Maheshi U. Chhaya
}

Department of Pharmacology, Topiwala National Medical College and B. Y. L. Nair Charitable Hospital, Mumbai Central, Mumbai, Maharashtra, India

Received: 30 June 2016 Accepted: 05 August 2016

*Correspondence to: Dr. Sagar V. Badwane, Email: dr.sagarbadwane@ gmail.com

Copyright: (C) the author(s), publisher and licensee Medip Academy. This is an openaccess article distributed under the terms of the Creative Commons Attribution NonCommercial License, which permits unrestricted noncommercial use, distribution, and reproduction in any medium, provided the original work is properly cited.

\begin{abstract}
Background: Coronary artery disease (CAD) is one of the most common causes of cardiovascular mortality and morbidity in developing countries like India. Initial management includes use of many antianginal drugs. There is wide variation in market prices of these drugs. This study was planned to analyse the percentage variation in prices amongst monotherapy and combination therapy of antianginal drugs manufactured and sold under different brand names in Indian market.

Methods: Price of antianginal drugs manufactured by different pharmaceutical companies, in the same strength and dosage forms was obtained from "Current Index of Medical Specialties (CIMS)" January-April 2016 and "Indian Drug Review (IDR)" Vol. XXII, Issue No.1, 2016. The difference in the maximum and minimum price of the same drug manufactured by different pharmaceutical companies and percentage variation in price per 10 tablets was calculated.

Results: Percentage variation in price for antianginal drugs marketed in India was found to be amlodipine $(5 \mathrm{mg}) 1128.57 \%$ followed by amlodipine $(10 \mathrm{mg}$ ) $1040 \%$ and amlodipine $(2.5 \mathrm{mg}) 780 \%$ as a monotherapy. Whereas atenolol $(25$ $\mathrm{mg})$, atenolol $(50 \mathrm{mg})$ and nicorandil $(10 \mathrm{mg})$ also showed significant percentage variation in prices $525 \%, 426.66 \%$ and $350.84 \%$ respectively. For combination therapy, percentage variation in prices were seen with amlodipine + atenolol $(5+50 \mathrm{mg}) 700 \%$, followed by atenolol + hydrochlorothiazide $(50+$ $12.5 \mathrm{mg}) 362.5 \%$ and Isosorbide dinitrate + aspirin $(5+75 \mathrm{mg}) 300 \%$.

Conclusions: There is a wide variation in the price of different brands of antianginal drugs available in India. The clinicians prescribing these drugs should be aware of these variations to reduce the financial burden of drug therapy.
\end{abstract}

Keywords: Antianginal drugs, Coronary artery disease, Price variation, Pharmaceutical companies

\section{INTRODUCTION}

Coronary artery disease (CAD) is one of the most common causes of cardiovascular mortality and morbidity in developing countries like India. According to reports from the National Commission on Macroeconomics and Health, 62 million people in India suffer from CAD with 23 million of these below 40 years of age. ${ }^{1}$ By $2020,60 \%$ of the CAD are expected to occur in India. ${ }^{1}$ The increase in incidence of CAD is due to rapid urbanization and changing lifestyle such as dietary changes, increased alcohol consumption, physical inactivity and increased prevalence of DM.-4
Anginal pain is the most specific presentation seen with $\mathrm{CAD}$ which is caused by myocardial ischemia as a result of obstruction in the coronary arteries. Other atypical symptoms include breathlessness, palpitation, tachycardia, dizziness and extreme weakness. Initial management includes use of antianginal drugs such as nitrates, calcium channel blockers (CCB) and beta blockers. If the symptoms are not adequately controlled, coronary angioplasty or bypass graft surgery is often required. ${ }^{5,6}$

As the prevalence of CAD is highest amongst elderly population in India, community doctors must prescribe antianginal drugs considering their financial status. 
Untreated CAD patients due to financial burden may lead to further complications such as cerebrovascular stroke, thromboembolic disorders and myocardial infarction. Thus it is necessary to make these antianginal agents available to the population at the minimum cost possible so that everyone can afford it and the complications of CAD can be avoided. ${ }^{7,8}$

The Indian pharmaceuticals market is the third largest in terms of volume and thirteenth largest in terms of value, as per the report by Equity Master. Also, India is the largest provider of generic drugs globally with the Indian generics accounting for 20 per cent of global exports. There is a wide variation in prices of these drugs, manufactured by different pharmaceutical companies in India. This study was planned to analyse the percentage variation in prices amongst monotherapy and combination therapy of antianginal drugs manufactured and sold under different brand names in Indian market.

\section{METHODS}

Price in Indian rupees (INR) of antianginal drugs manufactured by different pharmaceutical companies in India, in the same strength was obtained from "Current Index of Medical Specialties (CIMS)" January-April 2016 and "Indian Drug Review (IDR)" Vol. XXII, Issue No.1, 2016. The drug formulation being manufactured by only one pharmaceutical company or being manufactured by different pharmaceutical companies; however, in different strengths were excluded. Price of the antianginal drugs was calculated for an average of 10 tablets as the number of tablets available per strip varied.
Difference in the maximum and minimum price of the same drug formulation manufactured by different pharmaceutical companies and percentage variation in price was calculated.

Percentage price variation was calculated as follows:

$\%$ Price variation $=$

Maximum price of drug - Minimum price of drug $\times 100$ Minimum price of drug

\section{RESULTS}

The prices of a total 10 drugs ( 7 as a monotherapy and 3 as a combination therapy), available in 19 different formulations of antianginal drugs were analysed. These 19 different formulations were manufactured by different pharmaceutical companies.

\section{Monotherapy}

The Table 1 represents the price variation amongst monotherapy of antianginal drugs. A total of 16 drug formulations were analysed. Maximum percentage variation in prices were seen with amlodipine $(5 \mathrm{mg})$ $1128.57 \%$ followed by amlodipine $(10 \mathrm{mg}) 1040 \%$ and amlodipine $(2.5 \mathrm{mg}) 780 \%$. Whereas atenolol $(25 \mathrm{mg})$, atenolol $(50 \mathrm{mg})$ and nicorandil $(10 \mathrm{mg})$ also showed significant percentage variation in prices $525 \%, 426.66 \%$ and $350.84 \%$ respectively.

Table 1: Price variation amongst monotherapy of antianginal agents.

\begin{tabular}{|c|c|c|c|c|c|}
\hline Drug & Formulation & Dose (mg) & Min price (Rs) & Max price (Rs) & $\%$ Price variation \\
\hline \multirow{3}{*}{ Amlodipine } & \multirow{3}{*}{ 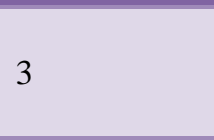 } & 2.5 & 5 & 44 & 780 \\
\hline & & 5 & 7 & 86 & 1128.57 \\
\hline & & 10 & 10 & 114 & 1040 \\
\hline \multirow{3}{*}{ Atenolol } & \multirow{3}{*}{3} & 25 & 4 & 25 & 525 \\
\hline & & 50 & 6 & 31 & 416.66 \\
\hline & & 100 & 14 & 44 & 214.28 \\
\hline \multirow{3}{*}{ Diltiazem } & \multirow{3}{*}{3} & 30 & 15 & 36 & 140 \\
\hline & & 60 & 28 & 58 & 107.14 \\
\hline & & 90 & 32 & 135 & 321.87 \\
\hline \multirow{2}{*}{ Glyceryl trinitrate } & \multirow{2}{*}{2} & 2.5 & 14 & 31 & 121.42 \\
\hline & & 6.5 & 22 & 46 & 109.09 \\
\hline \multirow{2}{*}{$\begin{array}{l}\text { Isosorbide } \\
\text { mononitrate }\end{array}$} & \multirow{2}{*}{2} & 30 & 26 & 61 & 134.61 \\
\hline & & 60 & 42 & 97 & 130.95 \\
\hline \multirow{2}{*}{ Nicorandil } & \multirow{2}{*}{2} & 5 & 49 & 185 & 277.55 \\
\hline & & 10 & 59 & 266 & 350.84 \\
\hline Trimetazidine & 1 & 20 & 20 & 83 & 315 \\
\hline
\end{tabular}


Table 2: Price variation amongst combination therapy of antianginal agents.

\begin{tabular}{|ll|lll|l|}
\hline Drug & Formulation & Dose $(\mathbf{m g})$ & Min price (Rs) & Max price (Rs) & \% Price variation \\
\hline Amlodipine + Atenolol & 1 & $5+50$ & 10 & 80 & 700 \\
\hline Atenolol + Hydrochlorothiazide & 1 & $50+12.5$ & 8 & 37 & 362.5 \\
\hline Isosorbide dinitrate + Aspirin & 1 & $5+75$ & 10 & 40 & 300 \\
\hline
\end{tabular}

\section{Combination therapy}

The Table no. 2 represents the price variation amongst combination therapy of antianginal drugs. A total of 3 drug formulations were analysed. Maximum percentage variation in prices was seen with amlodipine + atenolol $(5$ $+50 \mathrm{mg}) 700 \%$. Percentage variation in prices for atenolol + hydrochlorothiazide $(50+12.5 \mathrm{mg})$ and for Isosorbide dinitrate + aspirin $(5+75 \mathrm{mg})$ were found to be $362.5 \%$ and $300 \%$ respectively.

\section{DISCUSSION}

Presently the market size of the pharmaceutical industry in India stands at US\$ 20 billion. As on March 2014, Indian pharmaceutical manufacturing facilities registered with the US Food and Drug Administration (FDA) stood at 523, highest for any country outside the US. ${ }^{9}$ These evolving pharmaceutical industry in India contribute to the manufacture and sell of the same drug under different brand names. Various pharmaceutical companies manufacture large number of different drug formulations which are available at different prices to the Indian population. There is paucity of data regarding the analysis of prices of various antianginal drugs available in the Indian market.

As the prevalence of CAD is increasing in Indians, early management using antianginal drugs will reduce the cardiovascular mortality and morbidity. Therefore, this study was done to compare the prices of different brands of antianginal drugs manufactured by different pharmaceutical companies in India. The prices of these drugs are available in CIMS and IDR which are updated regularly.

This study revealed a wide variation in prices of antianginal drugs. Out of 19 drug formulations studied, 4 in the monotherapy and 1 in the combination therapy of antianginal drugs showed more than 500 percentage variation in prices. Maximum percentage variation in prices were seen with amlodipine (5 mg) $1128.57 \%$ amongst monotherapy and with amlodipine + atenolol $(5$ $+50 \mathrm{mg}) 700 \%$ amongst combination therapy of antianginal drugs.

Despite increasing growth in pharmaceutical market in India, the Indian population is not getting benefited because of their low socioeconomic status. Physicians play an important role in prescribing drugs to patients and they should prescribe drugs according to their financial condition. Physicians must notify the government about the market availability of these expensive drugs so that the Indian Government could reduce the pricing of antianginal agents by bringing them under Drug Pricing Control Order (DPCO). The drugs under DPCO have minimum percentage variation in prices than the drugs which do not come under it. ${ }^{10,11}$

Some previous price analysis studies of oral hypolipidemic drugs, antiepileptic drugs, oral fluoroquinolone antibiotics and anxiolytic drugs have also showed such a wide variation in prices in Indian market. ${ }^{12-15}$ This study also highlights the wide variation in prices amongst antianginal drugs marketed in India.

\section{Funding: No funding sources \\ Conflict of interest: None declared \\ Ethical approval: Not required}

\section{REFERENCES}

1. Idrayan A. Forecasting vascular disease cases and associated mortality in India. Reports of the National Commission on Macroeconomics and Health, Ministry of Health and Family Welfare, India; 2005:197-215.

2. Murray CJL, Lopez AD. Alternative projection of mortality and morbidity by cause 1990-2020: Global Burden of Disease Study. Lancet. 1997;349(9064):1498-504.

3. Deepa R, Arvind K, Mohan V. Diabetes and risk factors for coronary artery disease. Curr Sci. 2002;83:1497-505.

4. Gupta R, Sharma KK, Gupta A, Agrawal A, Mohan I, Gupta VP, et al. Persistent high prevalence of CV risk factors in the urban middle class in India: Jaipur Heart Watch-5. J Assoc Physicians India. 2012;60:11-6.

5. National Institute for Health and Clinical Excellence. Management of stable angina. (Clinical guideline 126) 2011. Available at http://guidance.nice.org.uk/CG126. Accessed on 14 April 2016.

6. Fihn SD, Gardin JM, Abrams J, Berra K, Blankenship JC, Dallas AP, et al. 2012 ACCF/AHA/ACP/AATS/PCNA/SCAI/STS

Guideline for the diagnosis and management of patients with stable ischemic heart disease: a report of the American College of Cardiology Foundation/American Heart Association Task Force on Practice Guidelines, and the American College of 
Physicians, American Association for Thoracic Surgery, Preventive Cardiovascular Nurses Association, Society for Cardiovascular Angiography and Interventions, and Society of Thoracic Surgeons. J Am Coll Cardiol. 2012;60:e44-164.

7. Lofholm PW, Katzung BG. Rational prescribing and prescription writing. In: Katzung BG, Trevor AJ, Editors. Basic and Clinical Pharmacology, 13th Edition. New Delhi: Tata McGraw-Hill Education Private Limited; 2015:1108-1117.

8. Satoskar RS, Bhandarkar SD, Rege NN. Pharmacotherapy of angina pectoris, acute MI and peripheral vascular diseases. In: Satoskar RS, Bhandarkar SD, Rege NN, Editors. Pharmacology and Pharmacotherapeutics, $24^{\text {th }}$ Edition. New Delhi: Elsevier Ltd; 2015:398-415.

9. Indian Brand Equity Foundation. Introduction: Indian Pharmaceutical Industry. Available at http://www.ibef.org/industry/pharmaceuticalindia.aspx. Accessed on 14 April 2016.

10. Das SC, Mandal M, Mandal SC. A critical study on availability and price variation between different brands: impact on access to medicines. Indian $\mathrm{J}$ Pharm Sci. 2007;69(1):160-3.

11. Frazier LM, Brown JT, Divine GW, Fleming GR, Philips NM, Siegal WC, et al. Can physician education lower the cost of prescription drugs? A prospective, controlled trial. Ann Intern Med. 1991;115(2):116-21.

12. Chawan VS, Gawand KV, Badwane SV. Cost analysis of oral hypolipidemic agents available in India. Int J Basic Clin Pharmacol. 2014;3:1-4.

13. Phatak AM, Hotwani JH, Deshmukh KR, Panchal SS, Naik MS. Cost analysis of long established and newer oral antiepileptic drugs available in the Indian market. Int J Med Res Health Sci. 2015;4(4);744-8.

14. Chawan VS, Gawand KV, Badwane SV. Fluoroquinolones in India-Are we prescribing it right: A cost variation study. Natl J Physiol Pharm Pharmacol. 2015;5:306-8.

15. Chawan VS, Badwane SV, Gawand KV, Chhaya MU. Analysis of price variation amongst different formulations of anxiolytic drugs available in Indian market. Int J Res Med Sci. 2016;4:2398-401.

Cite this article as: Chawan VS, Badwane SV, Gawand KV, Chhaya MU. Price analysis of antianginal drugs available in Indian market. Int J Basic Clin Pharmacol 2016;5:1991-4. 